\title{
Assessment of three plant extracts to obtain silver nanoparticles as alternative additives to control biodeterioration of coatings
}

\author{
L. Barberia-Roque ${ }^{\mathrm{a}, *}$, Erasmo Gámez-Espinosa ${ }^{\mathrm{a}}$, M. Viera ${ }^{\mathrm{a}, \mathrm{b}}$, N. Bellotti ${ }^{\mathrm{a}, \mathrm{b}}$

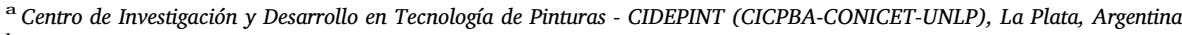 \\ ${ }^{\mathrm{b}}$ Universidad Nacional de la Plata, Argentina
}

\section{A R T I C L E I N F O}

\section{Keywords:}

Green synthesis

Silver nanoparticles

Antimicrobial additive

Coatings

Biodeterioration control

\begin{abstract}
A B S T R A C T
The control of biodeterioration has led to the development of new additives for the application in coating formulations. Antimicrobial nanoparticles obtained from aqueous plant extracts are promising; it is accessible, effective, low cost and eco-friendly. The aims of this research were to assess, for the first time, the use of aqueous extracts from three Argentine native plants: Schinus molle, Equisetum giganteum, and Ilex paraguariensis Saint Hilaire, for the synthesis of silver nanoparticles to be applied to antimicrobial coating formulations. The particles were identified and characterized by UV-vis spectroscopy, Fourier transformed infrared spectroscopy, Transmission electron microscopy and Scanning electron microscopy. The antimicrobial activity assays were carried on against bacterial and fungal strains: Escherichia coli (ATCC 11229), Staphylococcus aureus (ATCC 6538), Chaetomium globosum (KU936228) and Alternaria alternata (KU936229). Quasy-spherical nanoparticles obtained from Equisetum giganteum with an average size of $20 \mathrm{~nm}$ showed the higher antimicrobial activity. MIC (Minimum inhibitory concentration) range between 3.3 and $67.5 \mu \mathrm{g} / \mathrm{mL}$ with the different test strains and were integrated to an indoor acrylic waterborne paint formulation. The paint formulated with a silver concentration of $0.015 \mathrm{wt} \%$ proved to be more effective to inhibit the development of fungal and bacterial biofilms.
\end{abstract}

\section{Introduction}

Most bacterial and fungal species alternate between planktonic and sessile states, this last one comprise the attachment to surfaces and development of biofilms (Donlan, 2002). Microbial communities change the properties of materials where they growth due to their vital activities which becomes more important and when materials have economic importance (Allsopp, 2004; Morton and Surman, 1994). This phenomenon is defined as biodeterioration. In addition, these cell communities and the associated risk of infection is one of the most serious complications in food industries, hospitals and community settings (Banerjee et al., 2011; Humphreys, 2014). Therefore, prevent the attachment of the microorganisms which is the first step in biofilm development it is a promising approach for an antimicrobial paint. This kind of paints contains one or more antimicrobial additives. The most used are carbamates and isothiazolones, especially, halogenated derivatives of these (Falkiewicz-Dulik et al., 2015). Actually more ecofriendly possibilities are intensively studied like plant extracts and derivatives (Hendessi et al., 2016; Jaiswal et al., 2013; Matan et al., 2012; Sharmin et al., 2013). Then, the main issue is to seek new environmental friendly formulations to efficient and functional antimicrobial coatings and paints.

Silver is used as an alternative disinfectant in applications in which those traditional such as chlorine may result corrosive or in the formation of toxic by-products (Gerba et al., 2007). Silver nanoparticles (AgNPs) showed an effective broad spectrum of antimicrobial activity although the responsible mechanism is not yet completely clarified (Singh et al., 2016a; WHO, 1996). There are studies that point out different cellular target and actions such as: disturbance of the cell membrane; alteration of cellular DNA and proteins, electron transport, nutrient uptake, protein oxidation, or membrane potential; or the generation of reactive oxygen spices (ROS), which lead to cell death (Lok et al., 2006; Morones et al., 2005; Singh et al., 2016a). In addition nanoparticles release silver ions which seem to reinforce the biocidal activity (Le Ouay and Stellacci, 2015). Several of the cited effects are based on the interaction of the NPs with sulfur-containing proteins in the cell membrane and the phosphorus-containing molecules, therefore, it is believed that inhibits DNA replication, expression of ribosomal and other cellular proteins (Chung and Toh, 2014). Some cited mechanisms are expected to be found in both antibacterial and antifungal activities. Although there is less published data about fungi some interesting studies are carried out. Kasprowicz et al. found that Fusarium culmorum

\footnotetext{
* Corresponding author.

E-mail address: 1.barberia@cidepint.gov.ar (L. Barberia-Roque).
} 
(pathogen of crops) spores exposed to $2.5 \mu \mathrm{g} / \mathrm{mL}$ solution of AgNPs greatly reduced the number of germinating fragments and sprout length (Kasprowicz et al., 2010). Kim et al. tested AgNPs against Candida albicans and determined a MIC of $2 \mu \mathrm{g} / \mathrm{mL}$ approximately the same level of the amphotericin B a known antifungal which besides showed higher hemolytic activity than NPs (Kim et al., 2009). Further confirmed that NPs affected yeast cells by attacking their membranes, thus disrupting membrane potential (Kim et al., 2009). More recent studies by Mitra et al. documented AgNPs mediated inhibition of carcinogenic mycotoxin and secondary metabolite, aflatoxin B1 in Aspergillus parasiticus and they observed that the inhibition was not due to Ag ions since it was associated with the mycelial uptake of Ag NPs (Mitra et al., 2017).

Compared with others antimicrobial agents, silver is not considered a hazardous substance (Weber and Rutala, 2013). Only a small percentage of silver is absorbed and retention rates in humans and laboratory animals range between $0 \%$ and 10\% (Gorchev and Ozolins, 2011). The toxicity of silver ions and AgNPs has been studied against human fibroblast and the results indicate that silver ions are cytotoxic against the tested cell lines at $\mathrm{LC}_{100}$ values (the concentrations of silver lethal to $100 \%$ of the cells) equal to $1 \mu \mathrm{g} / \mathrm{mL}$, whereas the AgNPs shows a cytotoxic effect only at concentrations higher than $30 \mu \mathrm{g} / \mathrm{mL}$ (Panáček et al., 2009). Due to the lower mammalian cytotoxicity, generally, AgNPs are preferred to silver ions and they are highly considered in biomedical fields (Durán et al., 2016; Park et al., 2011).

There are two main approaches to obtain nanoparticles: reduce in size a suitable material (top-down) or build them from elemental entities like atoms and molecules (bottom-down) (Mittal et al., 2013). Top-down use physical or chemical methods that frequently consume too much energy and produce nanoparticles with imperfections in the surface (Thakkar et al., 2010). Milling is a typical example of a topdown procedure which is solvent-free, greener and economical (Landge et al., 2017). On the other hand, bottom-up approach appeals to chemical or biological synthesis which usually produces colloidal dispersions of particles with fewer defects and more homogeneous chemical composition (Cao, 2004; Singh, 2016).

Wet-chemical procedures are the most widely used for the synthesis of metallic nanoparticles and involve growing nanoparticles in a liquid medium containing reducing (eg, sodium borohydride or methoxy polyethylene glycol or hydrazine) and stabilizing agents (eg, sodium dodecyl benzyl sulfate or polyvinyl pyrrolidone or citrate) (Badawy et al., 2010; Singh, 2016). The drawbacks of chemical methods include contamination from precursor chemicals, toxic solvents, and generation of hazardous by-products. These issues have increased the interest in the exploration of eco-friendly alternatives framed in green syntheses like bio-reduction or biological methods (Singh et al., 2016b). These methods use cells as nanofactories or the extracts obtained from them (Mittal et al., 2013). Several bacteria, fungi, plants and marine algae have been reported for the last two decades to the biogenic nanoparticle synthesis (Baker et al., 2013; Durán et al., 2007; Elbeshehy et al., 2015; Singh et al., 2015). Plant extracts could be advantageous over other environmentally benign processes due to they eliminate the cost of maintaining cell cultures and also are suitably for large-scale synthesis (Kumar and Yadav, 2009). The source of the plant extract is known to influence the characteristics of the nanoparticles due to different extracts contain different concentrations and combinations of organic reducing and capping agents (Mittal et al., 2013). This is a promising method taking into account the great diversity of plants with a wide group of biomolecules that could to be used. The exact mechanisms by which plant extracts promote synthesis and stabilization have not been elucidated yet. The process appears to be close to the mechanisms of bio-mineralization by which plants precipitate minerals ( $\mathrm{He}$ et al., 2014). In this sense, the aqueous plant extracts contain metabolites such as polyphenols, flavonoids, terpenoids and alkaloids that can be responsible for the bioreduction of metal ions (Huang et al., 2007; Mittal et al., 2013). Based on the analysis of infrared spectra some studies propose proteins, terpenoids, and flavonoid as possibly responsible for the reduction of $\mathrm{Ag}^{+}$ions (Shankar et al., 2003; Makarov et al., 2014). In addition to this, Shankar et al. observed that comparing the use of Pelargonium graveolens extract with earlier studies, using bacteria or fungi, the reduction of the same ions was faster, completing more than the $90 \%$ within $9 \mathrm{~h}$, whereas using microorganisms were ranged from 24 to $124 \mathrm{~h}$ (Shankar et al., 2003). Reports also suggest that specific components founded in different plant species could be relevant to NPs synthesis; an example is an emodin, a resin with quinone compounds, which is present in xerophytes plants which are adapted to environments with little water (Baker et al., 2013; Singh et al., 2016b).

Another important issue to take into account at the time of the synthesis are the conditions (eg. $\mathrm{pH}$, temperature, and salt concentration) which greatly affect the shape, the size of the particles and with these the antimicrobial activity (Mittal et al., 2013). Morones et al. showed that bactericidal properties of the nanoparticles in the range of $1-100 \mathrm{~nm}$ are size dependent, been the more active those with size 1-10 nm (Morones et al., 2005). Pal et al. investigated the influence of different AgNPs shapes on antibacterial properties and they found that there was a dependency in this sense. AgNPs could be ordered in decreasing antimicrobial activity according to their shapes as follows: truncated triangular, spherical and rod respectively (Pal et al., 2007). But it should be considered that this is true whenever the NPs have a similar size (Raza et al., 2016). pH changes lead to changes in the charge of natural phytochemicals, which further affects the reduction of metal ions during the synthesis which may affect the morphology and yield of nanoparticles (Singh et al., 2016b). Temperature is another important factor affecting the formation of nanoparticles in plant extracts; in general, its elevation increases the reaction rate and efficiency of nanoparticle synthesis (Makarov et al., 2014).

The addition of AgNPs in coating and paint formulations to prevent biodeterioration has been reported. Zeilecka et al. found that the addition of sol-gel particle-supported Ag or Cu NPs $(0.1 \mathrm{mg} / \mathrm{L})$ to silicon acrylic emulsion paints improved their antifungal activity although not $100 \%$ of inhibition was observed (Zielecka et al., 2011). Kumar et al. developed a more effective antimicrobial vegetable oil-based paint with embedded AgNPs but with a higher silver concentration (34 mg of silver benzoate/4.8 $\mathrm{g}$ of alkyd paint). AgNPs were produced in a single step at ambient conditions without using external reagents (Kumar et al., 2008). Holtz et al. demonstrated that $1 \%(\mathrm{~m} / \mathrm{v})$ AgNPs supported on silver vanadate nanowires dispersed in a commercial water-based paint showed effective antibacterial activity (Holtz et al., 2012). Waterborne acrylic paints with zeolites exchanged with $\mathrm{Ag}^{+}$and $\mathrm{Zn}^{2+}$ proved to inhibit the development of Aspergillus niger in a concentration of $260 \mathrm{mg} / \mathrm{L}$ and $200 \mathrm{mg} / \mathrm{L}$ respectively (Pereyra et al., 2014). A strategy in the formulation of this kind of paint is adding a pigment usually used, such as, $\mathrm{TiO}_{2}$ or $\mathrm{CaCO}_{3}$ with AgNPs associated ("decorated"). In this sense Dominguez-Wong et al. prepared acrylic paints with $\mathrm{TiO}_{2}$ "decorated" with AgNPs (15\%v/v of a water dispersion of the particles) and assessed their antibacterial biofilm activity at different humidity conditions, finding that at lower relative humidity the antibacterial activity dropped significantly (Dominguez-Wong et al., 2014).

The aim of this research was to assess the use of aqueous extracts from three native argentine plants: Schinus molle "anacahuita" (A), Equisetum giganteum "cola de caballo" (E) and Ilex paraguariensis Saint Hilaire "yerba mate" $(\mathrm{Y})$ to obtain suspensions with AgNPs for their application as additives to antimicrobial coatings. These plants are abundant and traditionally used in infusions due to their medicinal potentials (Francescato et al., 2013; Machado et al., 2007). The synthesized particles were characterized by UV-vis spectroscopy, Fourier transformed infrared spectroscopy (FTIR) and transmission electron microscopy (TEM). The antimicrobial activity was evaluated against bacterial and fungal strains: Escherichia coli (ATCC 11229), Staphylococcus aureus (ATCC 6538), Alternaria alternata (KU936229) and Chaetomium globosum (KU936228), respectively. Bacterial strains are important due to their role in nosocomial infections (Chung and Toh, 
2014). The fungal strains used were isolated from biodeteriorated acrylic paint in a previous work and beside high paint film defacement produce mycotoxins, which are toxic to mammals (Bellotti et al., 2015; Olaf and Samson, 2011; Gaylarde et al., 2011).

\section{Materials and methods}

\subsection{Obtaining silver nanoparticles}

\subsubsection{Plant extract preparation}

Three different plants: Schinus molle "anacahuita" (A), Equisetum giganteum "cola de caballo" (E) and Ilex paraguariensis Saint Hilaire "yerba mate" (Y) were used. The leaves of A and E were collected in vivarium "Aula Viva" of "Facultad de Ciencias Naturales y MuseoUniversidad Nacional de la Plata, Buenos Aires, Argentina".

The abundance of phenolic compounds is a common denominator among the three plants. Some authors have published chromatographic studies on the chemical composition of these plants. For example, glucosylated kaempferol derivatives are very abundant flavonoids. In Schinus molle are abundant beudesmol; limonene, a-phellandrene, myrcene, elemol, and caryophyllene (Machado et al., 2007; Salem et al., 2016). The highest values of phenolic contents have been found in water extract fraction, in comparison with other fractions of the same plant.

E. giganteum equisetumpyrone was found as one of the major constituents, together with other di-O-hexoside styrylpyrone, in the aerial parts as well as phenolic derivatives such as glucosylated kaempferol,quercetin and caffeic acid (Francescato et al., 2013).

Aquos extract of Ilex paraguayensis showed majority compound chlorogenic acid, caffeine and theobromine. This plant has a high content of phenolic compounds, related to its known antioxidant activity (Bastos et al., 2006).

Firstly, the plants were decontaminated with a $2 \% \mathrm{v} / \mathrm{v}$ solution of $\mathrm{NaClO}$ and washed with distilled water (DW). Then leaves were dried at $50{ }^{\circ} \mathrm{C}$ to constant weight. Y source was "Yerba mate" (Rosamonte, Argentina) which is commercialized crushed and is suitable for human consumption. These plants are abundant and traditionally used in infusions due to their traditional medicinal potentials known by the native peoples (Francescato et al., 2013; Machado et al., 2007). The aqueous extracts were obtained by liquid-solid extraction method, $10 \mathrm{~g}$ of the leaves were put in contact with $100 \mathrm{~mL}$ of Milli-Q water at $80^{\circ} \mathrm{C}$ for $3 \mathrm{~min}$ filtered and kept in caramel flasks, at $4^{\circ} \mathrm{C}$, until to be used (Arunachalam et al., 2012).

\subsubsection{Synthesis of nanoparticles}

The nanoparticle synthesis with each of the three plants was done mixing $10 \mathrm{~mL}$ of the extract with $90 \mathrm{~mL}$ of $\mathrm{AgNO}_{3}$ solution at a regulated temperature $\left(60^{\circ} \mathrm{C}\right)$, under constant stirring. Due to the amount of the $\mathrm{AgNO}_{3}$ added to the synthesis system, the final concentrations were: $10^{-1} \mathrm{M}$ and $10^{-2} \mathrm{M}$, correspondingly. The $\mathrm{pH}$ of the final suspensions was regulated to 7 with $\mathrm{NH}_{4} \mathrm{OH} 50 \% \mathrm{v} / \mathrm{v}$. The particles in suspension were kept in the fridge at $4{ }^{\circ} \mathrm{C}$ in caramel flasks. All solutions were prepared with Milli-Q water.

\subsubsection{Characterization of the nanoparticles}

UV-vis spectroscopy was proven to be useful to check the AgNPs formation. The method is based in that the reduction of the metallic ions in nano-size produce, in the case of silver, a solution with an intense band at $400-450 \mathrm{~nm}$, attributed to the collective excitation of the surface electrons (superficial plasmonic absorption) (Kumar et al., 2014; Mulvaney, 1996). Spectra between 300 and $600 \mathrm{~nm}$ were obtained using quartz cuvette: 1,30 and 90 days after synthesis in order to assess the stability of the particles. As blank a solution of the extract, with the same dilution, was used. The measurements were performed in a Spectrum spectrophotometer (SP 2000 UV) Device spectral slit width is $5 \mathrm{~nm}$. The range is within $200-1000 \mathrm{~nm}$ delimited by the device. This operation was made "point by point", manually.

The Fourier transform infrared spectroscopy (FTIR) spectra were determined by transmittance. For that, a potassium bromide disk was obtained. Although the nanoparticles were purified, organic compound from plant extracts adsorbed on their surfaces can remain. The AgNPs were purified by repeated centrifugation at $15.000 \mathrm{rpm}$ for $20 \mathrm{~min}$ at $20^{\circ} \mathrm{C}$ followed by re-dispersion of the pellet in Milli-Q water (Arunachalam et al., 2012). This procedure was repeated three times. The pellet was dried at $28^{\circ} \mathrm{C}$.

The size and shape confirmation was carried out by Transmission Electron Microscopy (TEM). Micrograph of the AgNPs suspensions obtained were taken with a Gatan Erlangshen CCD model 785 ES1000W coupled with the Transmission Electron Microscope JEOL model100 CX II. Gatan Digital Micrograph was the program used to realize images processing. In not spherical nanoparticles, the longest diameter was chosen like representative measure. From the digitized images, the particles were processed to obtain the statistical distribution of sizes.

To obtain a panoramic vision about nanoparticles Scanning electron microscope (SEM), in high vacuum conditions $\left(10^{-6}\right.$ Torr) was performed. The microscope was a Philips FEI Quanta 200. Energy dispersive spectrometer for chemical analysis using X-rays (EDS) was performed too.

\subsection{Antimicrobial assays}

The antimicrobial assays were performed against bacterial and fungal strains: Escherichia coli (ATCC 11229), Staphylococcus aureus (ATCC 6538), Alternaria alternata (KU936229) and Chaetomium globosum (KU936228) respectively.

\subsubsection{Disc diffusion test}

Antibacterial and antifungal properties of the synthesized products were investigated using the agar diffusion method on plates with Mueller-Hinton Agar (MHA) and Malt Extract Agar (MEA) culture medium, respectively. Six mm diameter paper discs were impregnated, with $6 \mu$ l of the suspensions with AgNPs.

E. coli (ATCC 11229) and S. aureus (ATCC 6538) were grown in Mueller-Hinton broth. A $24 \mathrm{~h}$ culture was used to seed plates. Each strain was scattered uniformly on the individual plates by swabbing. Plates were incubated at $37^{\circ} \mathrm{C}$ for $24 \mathrm{~h}$. The inoculum was adjusted using phosphate buffer saline (PBS) by spectrophotometry at $620 \mathrm{~nm}$ to a DO of 0.1 which correspond to $10^{8} \mathrm{UFC} / \mathrm{mL}$.

Spore suspensions were prepared from C. globosum (KU936228) and A. alternata (KU 936229) cultures with 25-30 days of incubation at $28^{\circ} \mathrm{C}$ for de antifungal assays. The inoculum concentration was adjusted to $10^{5}$ spores/mL employing a Neubauer chamber. Plates with $15 \mathrm{~mL}$ of MEA inoculated with $200 \mu \mathrm{L}$ of spore suspension were prepared. Finally, plates were incubated for $48 \mathrm{~h}$ at $28^{\circ} \mathrm{C}$ (Fernández and Bellotti, 2017).

In both, antibacterial and antifungal tests, sterile DW was used as a negative control and a quaternary amine of known antibacterial and antifungal activity was used as a positive control. The antimicrobial activity of pure plant extracts and silver nitrate solutions was also investigated. At the end of incubation, plates were examined for zones of inhibition, which were measured considering diameters $<6 \mathrm{~mm}$ without antibacterial and antifungal activity and $>6 \mathrm{~mm}$, with antibacterial and antifungal activity. Diameters $=6$ were considered with antifungal activity but without antibacterial activity.

\subsubsection{Microdilution test}

Microdilution method performed with bacteria and fungi was similar to the Clinical and Laboratory Standards Institute (CLSI) and carried out with the suspensions that showed antibacterial and antifungal activity (M07-A9, 2012; M38-P, 2008).

This test was developed in multiwell plates to identify the minimum inhibitory concentration (MIC). The AgNPs suspensions were used in 
the form in which they had been prepared. Therefore, the concentration of $\mathrm{Ag}$ in the suspensions obtained and used to the antimicrobial assays was $1080 \mu \mathrm{g} / \mathrm{mL}$. The suspensions were diluted in a geometric progression from 54 to $1.7 \mu \mathrm{g} / \mathrm{mL}$ for the microdilution test; starting with diluted (1:20) suspensions with liquid culture medium. In the case of $C$. globosum to achieve the MIC we must to make the first dilution more concentrated (1:4) and the range was from 270 to $8.4 \mu \mathrm{g} / \mathrm{mL}$. The cultures liquid medium used were Muller-Hinton Broth (MHB) to bacteria and Malt Extract Broth (MEB) to fungi, respectively. The inoculums of bacteria and fungi were obtained using the same protocol that was described to the diffusion test. The final inoculum concentration of bacteria and fungi, in each well, were $10^{6} \mathrm{UFC} / \mathrm{mL}$ and $10^{5}$ spores/mL, respectively.

This antimicrobial protocol was complemented by plating each well in fresh agar medium to determinate the minimum biocidal concentration (MBC). In this way, it was able to discriminate biostatic from the biocidal activity. The antimicrobial assays were carried out in triplicate.

\subsection{Waterborne paints}

\subsubsection{Formulation and preparation}

The suspension with the higher antimicrobial activity at lower concentration was selected to be used as additive to formulate and prepare waterborne paints according to the base composition: $13.6 \%$ $\mathrm{TiO}_{2}, 25.9 \% \mathrm{CaCO}_{3}$ (natural), $2.0 \% \mathrm{CaCO}_{3}$ (precipitated), $6.3 \%$ acrylic resin (1:1), 3.6\% additives (antifoaming, cellulosic thickener, dispersants and surfactants) and $48.6 \%$ of DW (\% by mass). This formulation corresponds to the control paint (P) without biocides. Three paints with different silver concentrations were prepared on the basis of $\mathrm{P}$ formulation replacing part of the water by the suspension. The concentrations assayed were: $5.8,10$ and $15 \mathrm{mg}$ of silver per $100 \mathrm{~g}$ of paint, labeled as P5, P10, and P15, respectively. The concentrations were selected taking into account bibliography data (Bellotti et al., 2015).

\subsubsection{Fungal resistance test}

Slide glasses were painted with a paint prepared and cure. Then, they were irradiated with a germicide UV-lamp (Philips, 20 W) for $30 \mathrm{~min}$ on each side. Afterwards, three glasses of $6 \mathrm{~cm}^{2}$, of each paint sample, were place, in plates with Minimum Mineral culture medium (5 g NaCl, $1 \mathrm{~g} \mathrm{HK} \mathrm{HO}_{4}, 1 \mathrm{~g}\left(\mathrm{NH}_{4}\right) \mathrm{H}_{2} \mathrm{PO}_{4}, 1 \mathrm{~g}\left(\mathrm{NH}_{4}\right)_{2} \mathrm{SO}_{4}, 0.2 \mathrm{~g} \mathrm{MgSO}_{4}$, $3 \mathrm{~g} \mathrm{KNO}_{3}$ and $20 \mathrm{~g}$ of agar in $1000 \mathrm{~mL}$ of DW). The coating samples were inoculated with $50 \mu \mathrm{L}$ of the spore suspension $\left(10^{5}\right.$ spores $\left./ \mathrm{mL}\right)$ of C.globosum and A. alternata and incubated at $28^{\circ} \mathrm{C}$ for 1 month (Bellotti et al., 2013).

Fungal growth was evaluated according to ASTM D5590 standard specification. Consequently, observed growth on specimens are referred to percentage (\%) of area covered and has been rating as 0 (none, $0 \%$ ), 1 (trace of growth, <10\%), 2 (light growth, 10-30\%), 3 (moderate growth, 30-60\%), and 4 (heavy growth, 60-100\%).

Coatings exposed for 4 weeks by bio-resistance test were observed by SEM. The microscope was a Philips FEI Quanta 200, and the working conditions were low vacuum $\left(10^{-2}-1\right.$ Torr). Energy dispersive spectrometer for chemical analysis using X-rays (EDS) was used.

\subsubsection{Antibacterial biofilm tests}

Cultures of $24 \mathrm{~h}$ from bacterial strains were used to the inoculum preparation on MHB at $30{ }^{\circ} \mathrm{C}$ on a rotary shaker at $125 \mathrm{rpm}$ by $1 \mathrm{~h}$. The number of bacteria was adjusted to $10^{5} \mathrm{CFU} / \mathrm{mL}$. Slide glasses covered with each paint samples were cut in pieces $1.0 \mathrm{~cm} \times 2.5 \mathrm{~cm}$ and decontaminated by exposition to a germicide UV-lamp (Philips, $20 \mathrm{~W}$ ) for $30 \mathrm{~min}$ on each side. Painted glasses were vertically introduced in sterile amber flacks, completely covered with $7 \mathrm{~mL}$ MHB and incubated during 3 day at $30^{\circ} \mathrm{C}$. Then samples were withdrawn and washed, three times, with phosphate buffer solution (PBS) to detach non-adhered cells. The biofilm was fixed with a glutaraldehyde solution at $2 \% \mathrm{v} / \mathrm{v}$ in
PBS and observed by environmental scanning electron microscopes (ESEM). The microscope was a Philips FEI Quanta 200, and the working conditions were 6 Torr, $5{ }^{\circ} \mathrm{C}, 15 \mathrm{KV}$ (Stobie et al., 2010). Samples do not require being dehydrated allowing keep more natural morphology of biofilms (Bellotti et al., 2014).

\section{Results and discussion}

\subsection{Characterization of nanoparticles}

The suspensions with the AgNPs obtained from the mixture of $\mathrm{AgNO}_{3}$ solutions $\left(10^{-1} / \mathrm{A} 1\right.$ and $\left.10^{-2} \mathrm{M} / \mathrm{A} 2\right)$ with the plant extracts ( $S$. molle/A, E. giganteum/E and I. paraguariensis/Y) were labeled as A1A, $\mathrm{A} 2 \mathrm{~A}, \mathrm{~A} 1 \mathrm{E}, \mathrm{A} 2 \mathrm{E}, \mathrm{A} 1 \mathrm{Y}$, and $\mathrm{A} 2 \mathrm{Y}$, respectively. The colorless aqueous $\mathrm{AgNO}_{3} 10^{-2} \mathrm{M}$ change the color in each case after the addition of the plant extracts. In the case of E. giganteum extract became yellowish brown in few minutes. It is well known that this yellow color of the reaction mixture arises due to excitation of Surface Plasmon Resonance (SPR) vibration in the silver nanoparticles (Kumar et al., 2014; Mulvaney, 1996). The synthesis with $\mathrm{AgNO}_{3} 10^{-1} \mathrm{M}$ resulted in unstable products with the formation of dark precipitates in every case. UV-vis spectroscopy was carried out to confirm the presence of the AgNp. The Fig. 1A-C shows the UV-vis spectra of A2A, A2E, and A2Y with maximum absorption bands at $\sim 450 \mathrm{~nm}$ which confirm the presence of AgNPs. The bands differ in their broadening which is indicated that the particles were polydispersed (Agnihotri et al., 2014; Pasupuleti et al., 2013), being A2Y the widest one follow by A2A. In this sense, Agnihotri et al. showed that AgNPs with higher size dispersity presented lower antibacterial activity (Agnihotri et al., 2014). The spectrum of A2E, Fig. 1B exhibits a bell curve with a better-defined maximum and narrower than A2A and A2Y. Different shapes and sizes of nanoparticles are associated with characteristic UV visible spectra. AgNPs with spherical, triangular and rod shape presented characteristic plasmonic bands at $\sim 400,400 / 500$ and $600 \mathrm{~nm}$, respectively (Pal et al., 2007; Rai et al., 2009). Therefore, a high polymorphism of the NPs in the suspensions could lead to overlapping bands corresponding to the mixture of different shapes of them. This could explain the absorption between 500 and $600 \mathrm{~nm}$ observed in the suspensions obtained with $S$. molle and I. paraguariensis.

FTIR spectra demonstrated that plant metabolites such as sugars, terpenoids, polyphenols, alkaloids, phenolic acids, and proteins play an important role in the reduction of metal ions into nanoparticles and in supporting their subsequent stability (Mittal et al., 2013; Pasupuleti et al., 2013; Makarov et al., 2014). Several plants differ in the concentration and composition of these biologically active components and this may explain the morphological and size diversity of the NPs (Makarov et al., 2014). The FTIR spectra obtained from purified AgNPs were examined and showed in the Fig. 1D. The higher intensity and number of bands and peaks in the A2E spectrum compared to A2A and $\mathrm{A} 2 \mathrm{Y}$ is notorious. This would point out the greater interaction of the biomolecules from $E$. giganteum extract with the AgNPs than in the case of the other extracts. The band in the $3600-3000 \mathrm{~cm}^{-1}$ region is associated with $\mathrm{OH}$ groups present in aromatic or aliphatic alcohols (eg. terpene and polyphenolic compounds). The band observed at $1635 \mathrm{~cm}^{-1}$ may be attributed to carbonyl $-\mathrm{C}=\mathrm{O}$ stretching, present in peptide backbone and flavonoids (Pasupuleti et al., 2013). The peak around $1390 \mathrm{~cm}^{-1}$ could be assigned to a geminal methyl group. The bands 550 and $858 \mathrm{~cm}^{-1}$ are related to $\mathrm{C}-\mathrm{H}$ out of plane bend characteristics of aromatic phenols (Gurunathan et al., 2014). The important peak at $1026 \mathrm{~cm}^{-1}$ would be related to ether linkages. This matches with the study performed by Francescato et al. who proved that glucosylated kaempferol and quercetin derivatives were the most abundant flavonoids in E. giganteum (Francescato et al., 2013). The basic chemical structures of these flavonoids are shown in Fig. 1A-B of the supplementary material. This analysis shows that biomolecules bearing different functionalities are strongly associated with the AgNPs 

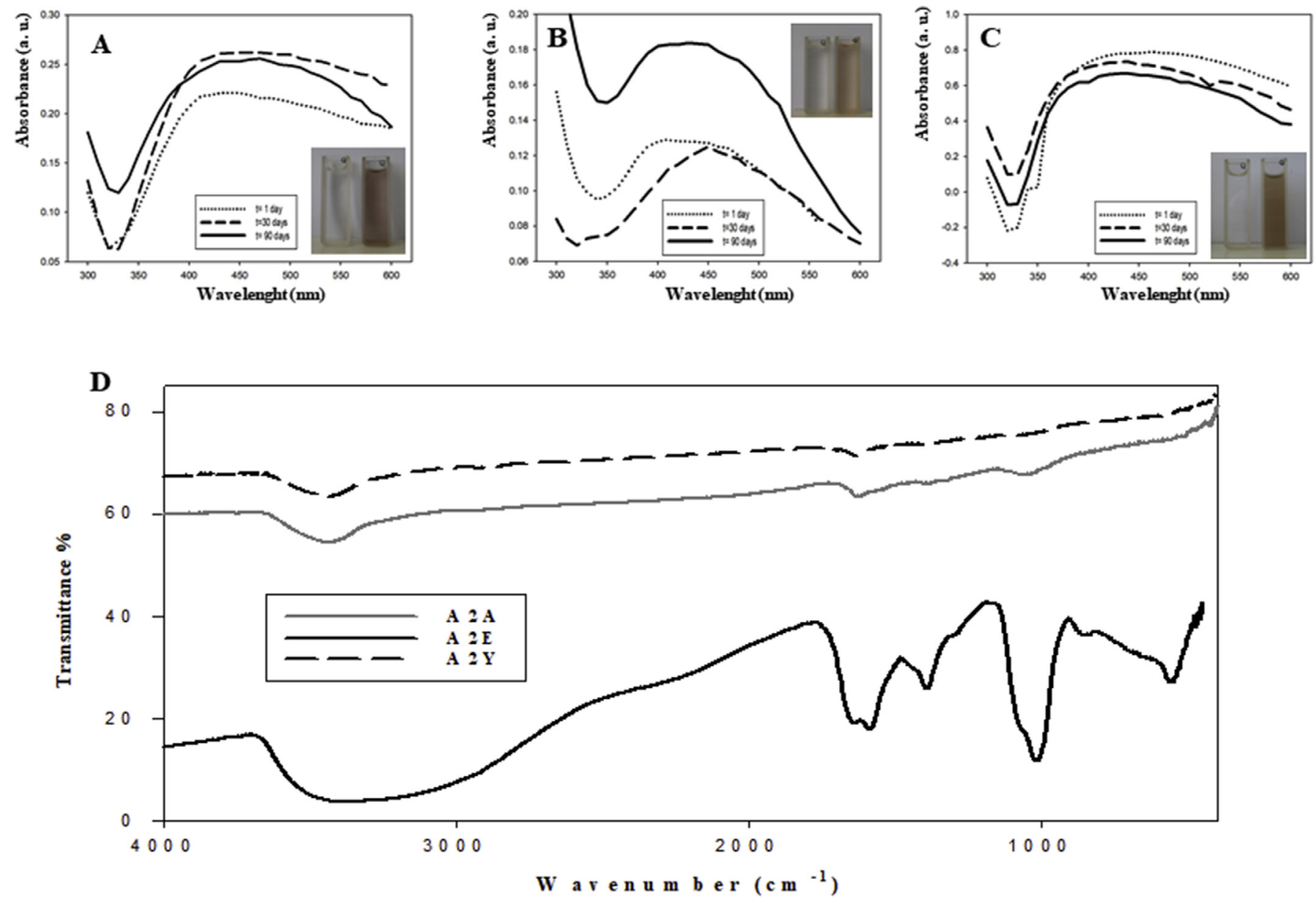

Fig. 1. (A-C) UV-Vis and (D) FTIR spectra of AgNPs obtained from: S. molle/A2A(A), E. giganteum/A2E (B) and Ilex paraguariensis/A2Y (C).

synthesized. As it was indicated above this would help to stabilize AgNPs (Sharma et al., 2009). On the base of these results, a possible mechanism for the reduction of $\mathrm{Ag}^{+}$is proposed in Fig. 1C of the supplementary material. In this scheme, $\mathrm{Ag}^{+}$ions can form intermediate complexes with phenolic hydroxyl groups in the $3^{\prime}$ and $4^{\prime}$ positions in flavonoids, such as kaempferol and quercetin, subsequently, undergo oxidation to quinone forms with consequent reduction of $\mathrm{Ag}^{+}$to $\mathrm{Ag}^{0}$ (Edison and Sethuraman, 2012; Terenteva et al., 2015). Then, $\mathrm{Ag}^{0}$ by nucleation form nanoparticles.

TEM micrographs in Fig. 2 A-F show the quasi-spherical AgNPs with a more homogenous shape for those obtained from E. giganteum (A2E) than A2A and A2Y which are the least regular. This observation was confirmed with SEM images obtained (Fig. 2A-C of the Supplementary materials). The histograms obtained by micrograph analysis in Fig. 2 show more dispersion in size of A2Y NPs with an average size of $41.0 \pm 2.0 \mathrm{~nm}$ compared to those from A2A and A2E whose averages sizes were $12.0 \pm 0.6 \mathrm{~nm}$ and $20.0 \pm 1.0 \mathrm{~nm}$, respectively.

Organic based material from plant extracts could be seen around the particles in TEM images, this was confirmed by EDS analysis (Fig. 2D-F of the supplementary materials) and the FTIR spectra (Fig. 1D) of the purified AgNPs. The EDS profile confirmed the significant presence of silver in all the cases studied with a characteristic peak observed at $\sim 3 \mathrm{keV}$, which is typical for the absorption of metallic silver nanocrystallites due to surface plasmon resonance (Kalimuthu et al., 2008). In addition to this, EDS profile showed characteristic peaks from organic matter: $\mathrm{C}, \mathrm{O}, \mathrm{S}, \mathrm{N}$ and $\mathrm{P}$.

\subsection{Disc diffusion}

The results from diffusion test in the Fig. 3 showed that in general the antibacterial activity of the synthesized products was superior to the antifungal activity. The plant extracts (E, A, and Y) did not show antimicrobial activity. The diffusion test showed that A2A and A2E were actives against both bacterial and fungal strains. It should be noted that A2E presented inhibition zones in all tested strains. A2Y only presented an intermediate activity inhibiting fungal growth on the disc against both fungi. Therefore, A2A and A2E were chosen for further evaluation to determine which is the most active to be incorporated in a coating formulation.

\subsection{Minimum inhibitory concentrations}

The MIC results obtained from microdilution test are shown in Table 1. The A2E inhibited at lowest concentrations, 3.3, 13.3, 3.3 and $67.5 \mu \mathrm{g} / \mathrm{mL}$, to the strains tested E. coli, S. aureus, A. alternata and $C$. globosum respectively, compared with those obtained from $S$. molle. The highest MIC was required to inhibit the growth of C. globosum in both cases. The reseeding of each well on plates confirmed that observed in microdilution assay for E. coli, S. aureus and A. alternata and not differences were obtained between inhibitory and biocidal concentrations. Plates from the reseeding test are shown in the Fig. 3 of supplementary materials. On the other hand, C. globosum exposed to NPs from $S$. molle and $E$. giganteum could grow in plates in all cases, thus showing its high resistance to these NPs activity. Therefore, no lethal dose was reached for C.globosum.

Although, AgNPs obtained from $S$. molle presented lower average 

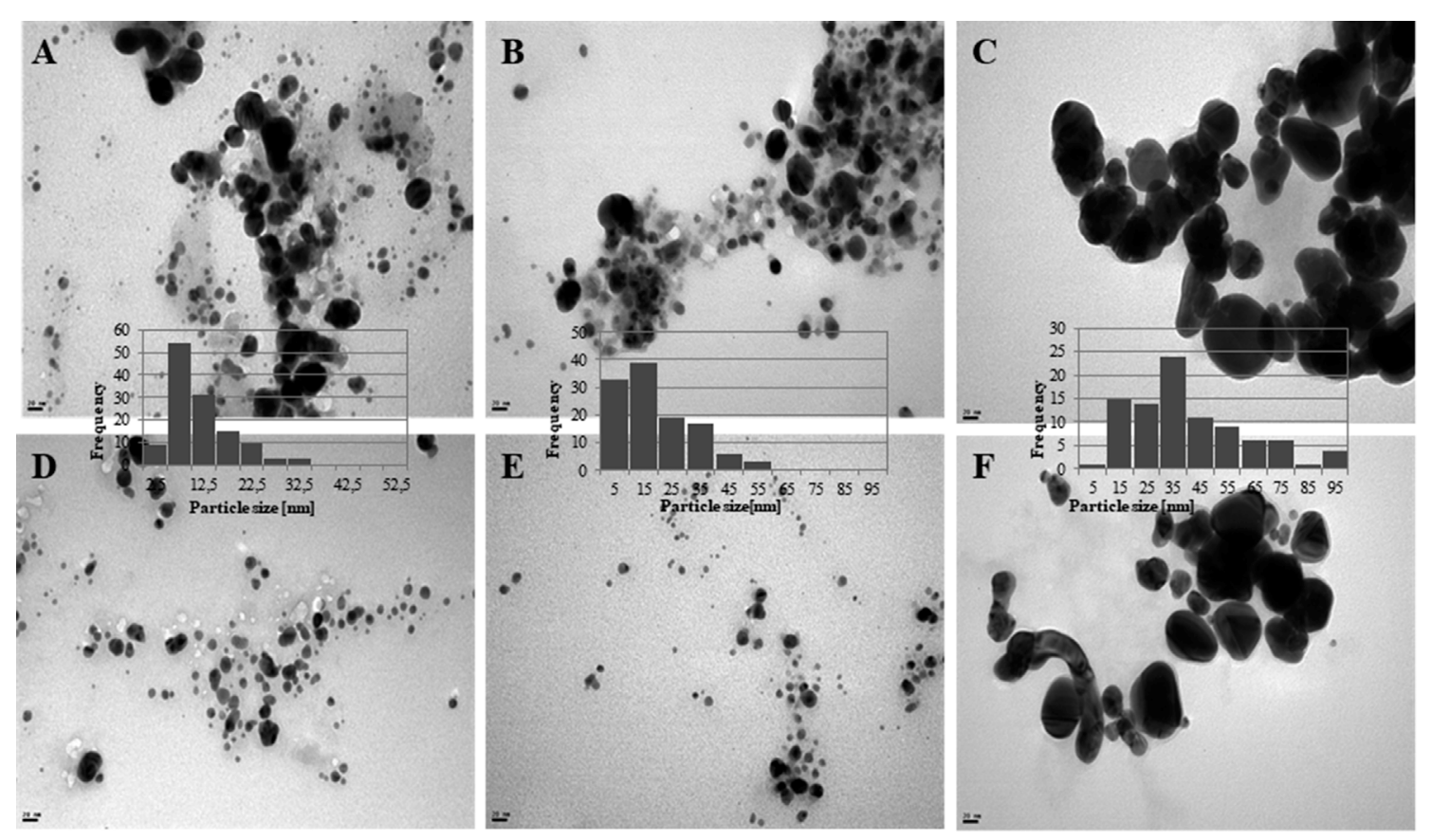

Fig. 2. TEM images and histograms from size distribution analysis of AgNPs/S. molle (A,D); AgNPs/E. giganteum (B,E) and AgNPs/Ilex paraguariensis A2Y(C,F). Magnification 270000x. The bar in each micrograph corresponds to $20 \mathrm{~nm}$.

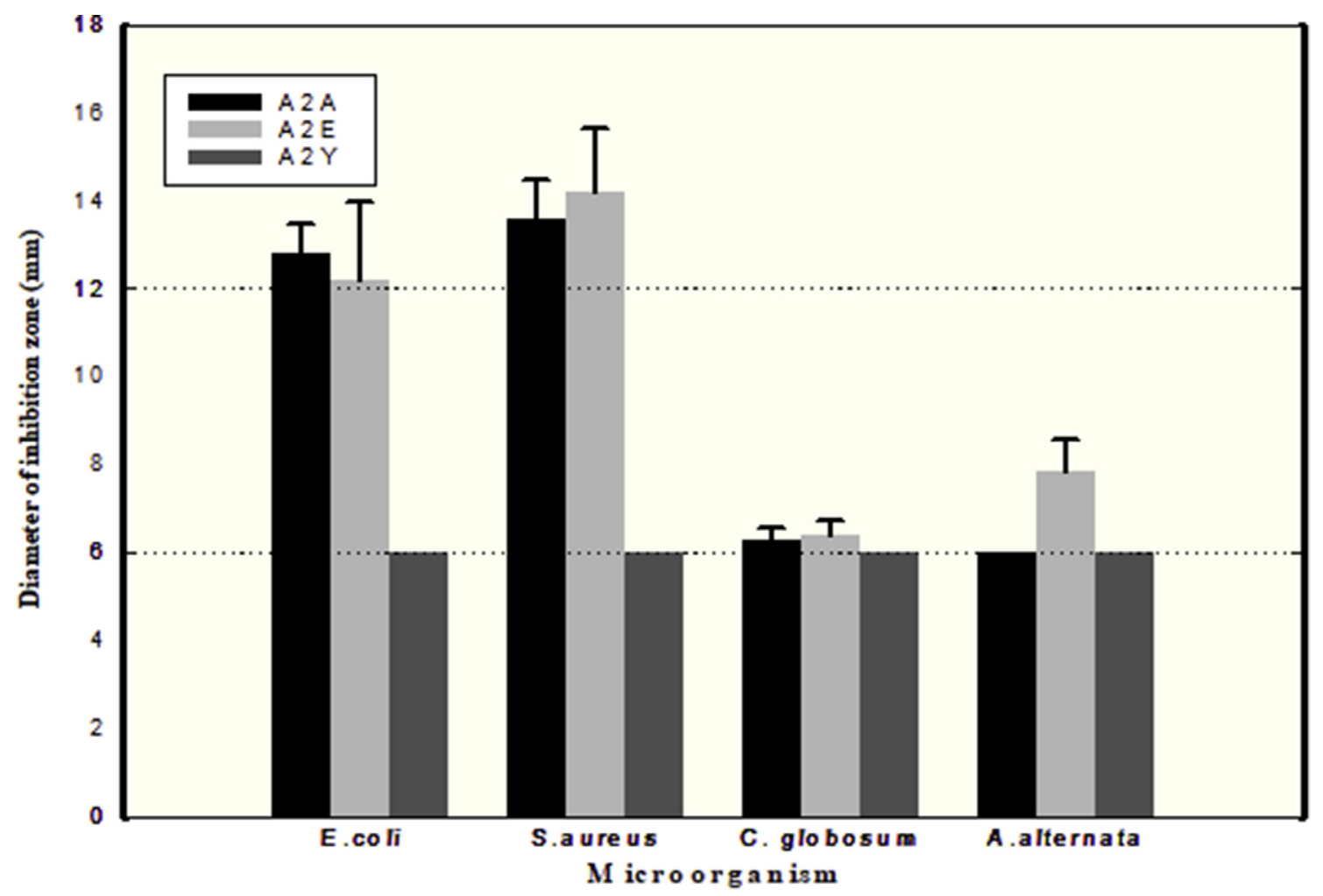

Fig. 3. Diffusion test: diameters of inhibition zones of AgNPs suspensions from: S. molle (A2A), E. giganteum (A2E) and Ilex paraguariensis (A2Y). The controls without AgNp no presented inhibition zones in any case. All plant extracts used did not show antimicrobial activity in any case.

Table 1

Microdilution test: minimum inhibitory concentration $(\mu \mathrm{gAg} / \mathrm{mL})$.

\begin{tabular}{lllll}
\hline Plant extract & E. coli & S. aureus & A. alternata & C. globosum \\
\hline S. molle & 13.3 & 54 & 13.3 & 135 \\
E. giganteum & 3.3 & 13.3 & 3.3 & 67.5 \\
\hline
\end{tabular}

size compared to NPs from E. giganteum this last one resulted more active against all strains tested, that could be attributed to the different biomolecules that would be stabilizing them and the less regular morphology observed in TEM and SEM for S. molle (Pal et al., 2007; Makarov et al., 2014).

Several AgNPs have been synthesized using different plant extracts. Zeng et al. obtained AgNPs $(<100 \mathrm{~nm}$ ) with Tetrapanax papyriferus and 

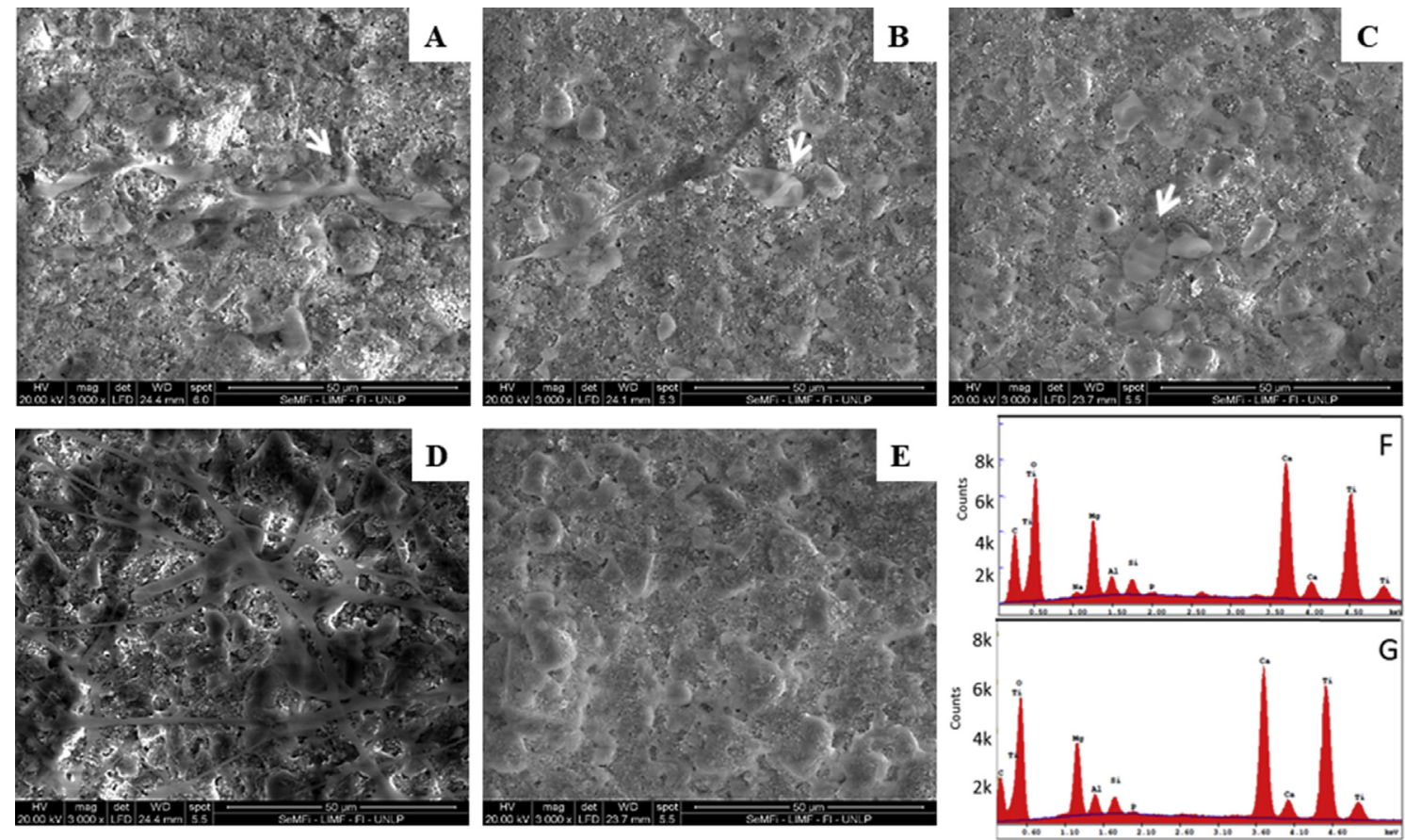

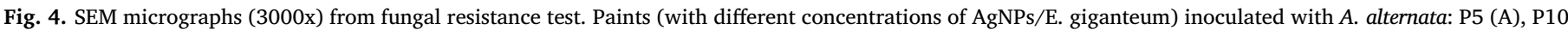
(B), P15 (C); P (control without biocide) (D) and P (E) not inoculated. EDS from samples inoculated: P (F) and P15 (G).

the resulted MIC were $14.1 \mathrm{mg} / \mathrm{L}$ and $28.1 \mathrm{mg} / \mathrm{L}$ for $E$. coli and Candida albicans, respectively. Krishnaraj et al. used Acalypha indica extract and the AgNPs (20-30 nm) showed antibacterial activity against E. coli and $V$. cholerae with a MIC of $10 \mu \mathrm{g} / \mathrm{mL}$ (Krishnaraj et al., 2010). Banasiuk et al. used water extract from four carnivorous plant species: D. muscipula, D. binata, D. spatulata and D. indica been the MIC of the AgNPs obtained in the same conditions, against $S$. aureus and C. albicans, ranged from 21.2 to $125.5 \mu \mathrm{g} / \mathrm{mL}$ and $42.5-170 \mu \mathrm{g} / \mathrm{mL}$ respectively (Banasiuk et al., 2017). Panáček et al. obtained NPs from the reduction of $\left[\mathrm{Ag}\left(\mathrm{NH}_{3}\right)_{2}\right]^{+}$by glucose, galactose, maltose and lactose with MIC against E. coli and S. aureus ranged from 3.4 to $27 \mu \mathrm{g} / \mathrm{mL}$ and $6.75-54 \mu \mathrm{g} / \mathrm{mL}$, respectively (Panáček et al., 2006). The variations in the inhibitory and biocidal activity of the AgNPs highly depend on the microorganism to which they are faced, synthesis conditions, microdilution assay conditions, reducing and stabilizing agents or plant extract used.

Panáček et al. reported fungicidal concentration to Candida species as high as $27 \mu \mathrm{g} / \mathrm{mL}$ and pointed out that fungicidal activity of the AgNPs was significantly lower than their bactericidal effects attributed to the less complex cell structure of prokaryotes compared to that of eukaryotes (Kvítek et al., 2008; Panáček et al., 2009, 2006). This has not been the case in the present work with A. alternata which presented MIC/MBC lower than S.aureus and similar to E. Coli. On the other hand, it is highlighted that of the four strains, the most resistant was the fungus C. globosum with a fungicidal activity no determined but $>$ $270 \mu \mathrm{g} / \mathrm{mL}$ (the higher one tested). In the present work as in the Panacek et al. it can be seen that even for the same strain, different MIC/ MBC were determined to AgNPs synthesized with different reducing agents. Therefore, there are so many factors involved in the antimicrobial activity of these NPs that is very difficult to make a generalization.

\subsection{Fungal resistance}

Suspension obtained from Equisetum giganteum was selected to elaborate the corresponding paints as it resulted the most active against all the tested strains compared with A2A and A2Y. Fungal resistance test to assess the formulated paints (P, P5, P10 and P15) was performed by exposing the coating samples to fungi growth during four weeks and at that time samples were rated using the scale proposed by ASTM D5590 standard.

Paints inoculated with C. globosum presented light growth, rating (R) as 2 in the case of P5. This performance was improved when AgNPs concentration increased in paint formulations and therefore an increase in the inhibitory activity was observed being the growth rating for P10 and P15 of $\mathrm{R}=0$ (none growth). Paint $\mathrm{P}$ presented higher fungal development with evident sporulation $(\mathrm{R}=3)$. Paint films inoculated with $A$. alternata yielded different results. The differences between P5 and the others formulations (P10 and P15) are lower than with $C$. globosum assays. The three paints showed light fungal growth $(\mathrm{R}=2)$ while the control presented heavy growth $(R=4)$. Photographic records of P (blank without antimicrobial additives) and P15 are shown in supplementary materials.

It is highlighted the change in the resistance of fungi used in the present study when changing the assessed system. The assay performed on paint film showed that $C$. globosum was more inhibited to grow in such conditions compared with A. alternata, the opposite performance was observed in the microdilution test. In this sense, in the present study, C. globosun presented a greater resistance against AgNPs in liquid medium than $A$. alternata. This could be attributed to the differentiated water requirements to colonize and grow on paint films and others building materials by different fungi. It is well known the higher water requirements of C.globosum which is capable of growing at the water activity (aw) $>0.9$ compared to that needed by $A$. alternata with an aw less than 0.9 (Nielsen, 2003).

To study in greater depth, the effects of the additive paint on the $A$. alternata development SEM micrographs were obtained and showed in Fig. 4. This fungus has been described as highly spoilage and resistant to low aw conditions (Olaf and Samson, 2011). Fig. 4A and B correspond with inoculated paint films from P5 and P10, respectively, and it can be seen the increase in inhibition of germination and growth (detail with white arrows) of hyphae with increasing of AgNp concentration. The spores observed on Fig. 4C (detail with the white arrow) were deposited as part of the inoculation to perform the assay and they failed 

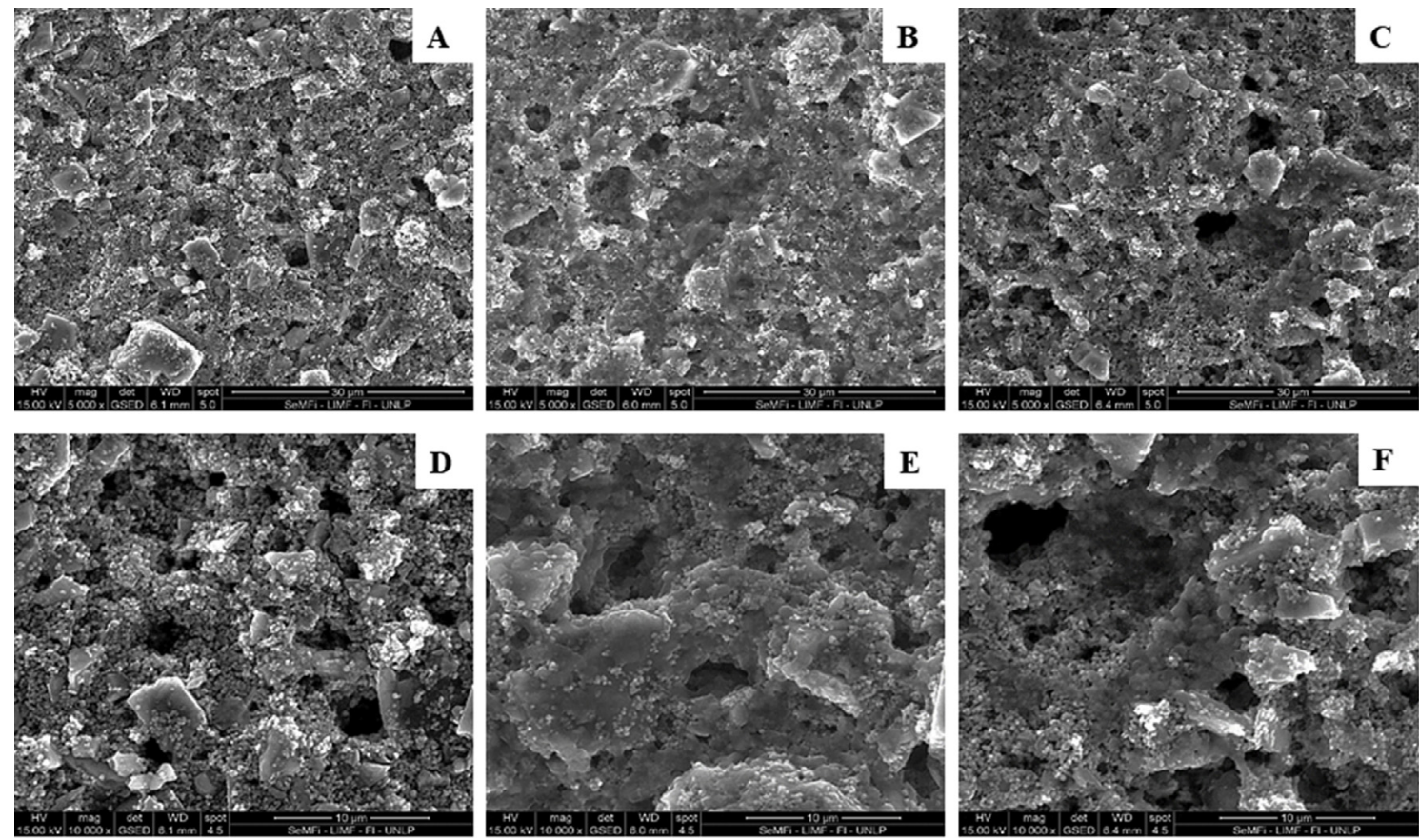

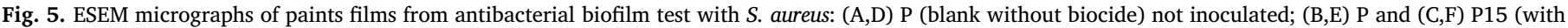
AgNPs/E. giganteum) inoculated. Note the inhibition in bacterial growth on P15. Magnification 5000x (A-C) and 10000x (D-F).

to germinate. Note in Fig. 4D the control coating $\mathrm{P}$ without biocides showed a high degree of fungal development with an important hyphae network which extends and interacts strongly with paint film. The Fig. 4E shows the aspect that presents the paint film of $\mathrm{P}$ without inoculation in the same observation conditions.

EDS results can be observed in Fig. 4F and G carried out on $\mathrm{P}$ and $\mathrm{P} 15$ respectively, and it was used to obtain a semi-quantitative surface analysis. It is can be observed the marked decrease in the quantity of carbon, an element associated with the fungal biomass when comparing $\mathrm{P}$ control without biocide in Fig. 4F with P15 in Fig. 4G. The silver present in P15 was not detected, probably to the low AgNPs concentration in paint films which was lower than the detection limit of the equipment. Latter evidence adds value to the present work, where it was possible to demonstrate antimicrobial activity of the nanoparticles even being added to very low concentrations in the paint formulation.

In a previous work with the same strains but with acrylic paints with AgNPs obtained by chemical synthesis (Bellotti et al., 2015) the bioresistance efficiency found was similar with a concentration of $5.8 \mathrm{mg} /$ $100 \mathrm{~g}$. In the present paper bio-resistance efficiency was improved related to C. globosum with a $\sim 2$-time higher concentration $(10 \mathrm{mg} /$ $100 \mathrm{~g}$ ) which corresponded with $100 \%$ of fungal inhibition but against A. alternata this was not achieved in any concentration. These results correspond to those obtained by Zielecka et al. with silicon acrylic paints with lower concentration of AgNPs (0.1 mg/L) which a $100 \%$ inhibition against $C$. globosum was not achieved. Aspergillus niger, Paecilomyces varioti, and Penicillium funiculosum showed similar results (Zielecka et al., 2011). On the other hand, waterborne acrylic paints assayed by Pereyra et al. with a higher concentration of $\mathrm{Ag} / \mathrm{Zn}$ - zeolite $(260 \mathrm{mg} / 200 \mathrm{mg} / \mathrm{L})$ as would be expected totally inhibit the development of Aspergillus niger (Pereyra et al., 2014).

\subsection{Aditivated pains $v$ s bacterial biofilm}

Taking into account the results obtained with the fungal resistance test and SEM assessing of paint films, P15 was selected to be confronted with pure cultures in the liquid nutrient culture medium of $E$. coli and S.aureus. Despite being very different from the conditions in which the biodeterioration of coated surfaces occurs, the conditions of this test make it possible to ensure that conditions for the formation of biofilm are favorable. The aforementioned is important to be able to determine the influence of A2E on the biofilm formation (Archer et al., 2011).

ESEM micrographs of coatings inoculated with $S$. aureus are shown in Fig. 5A-F. S. aureus, bacteria widely studied for its high capacity for biofilm formation, was tested against P15. A constituted and widely distributed biofilm is evident on paint $\mathrm{P}$ (control paint) in Fig. 5B (5000x) and with more detail in Fig. 5E (10000x). By contrast, an inhibited bacterial growth is observed in Fig. 5C and F, which allow appreciate the paint surface which is similar to the paint that has not been inoculated in Fig. 5Aand D.

Although coating P inoculated with $E$. coli showed a biofilm less developed compared to the $S$. aureus, an incipient bacterial growth can be seen in these samples. Differences between coating P and P15 (where no bacterial growth was observed) were evident. These micrographs are shown in Fig. 5 of supplementary materials. The surface of P15, is very similar to the non-inoculated control paint films which can be seen in Fig. 5A and D. Eco-friendly alkyd paint with AgNPs developed by Kumar et al. showed excellent antimicrobial properties by killing $S$. aureus and E. coli but with an AgNPs concentration $\sim 20$ times higher than ours. Similar results obtained Holtz et al. with a paint formulated with an even higher concentration $(1 \mathrm{~g} / 100 \mathrm{~mL})$ of AgNPs against $S$. aureus (MRSA) in agar diffusion assay. Waterborne acrylic formulation of Dominguez-Wong et al. with a lower AgNPs concentration $1.6 \mathrm{mg} /$ $100 \mathrm{~mL}$ ) not could inhibit the $100 \%$ of $S$. aureus (MRSA) growth while it was possible with $E$. coli (relative humidity $=90 \% / 35^{\circ} \mathrm{C}$ ).

\section{Conclusions}

It was possible to assess the use of aqueous extracts from three native Argentine plants to obtain silver nanoparticles. The synthesis product from Equisetum giganteum extract resulted in the most active against the four strains used in antimicrobial tests and was integrated into a waterborne coating formulation. The paint films obtained proved to be effective to inhibit fungal and bacterial biofilm development. The present work value is based on the use of an eco-friendly process to obtain a functional antimicrobial coating for the first time using three abundant native plants. This green approach has important advantages 
such as the ease with which the process can be scaled up and its economic viability.

\section{Acknowledgment}

Authors are thankful to "Aula Viva" Vivarium of Facultad de Ciencias Naturales y Museo- Universidad de la Plata and Dra. Sol Roselli for providing the plant samples. It is also to be highlighted the essential support of: Consejo Nacional de Investigaciones Científicas y Técnicas (CONICET), Comisión de Investigaciones Científicas de la provincia de Buenos Aires (CICPBA), Agencia Nacional de Promoción Científica y Tecnológica (ANPCyT) and Universidad Nacional de La Plata (UNLP). A special thanks to Dra. Cecilia Deyá for her support.

\section{Appendix A. aSupplementary data}

Supplementary data related to this article can be found at http://dx. doi.org/10.1016/j.ibiod.2018.06.011.

\section{References}

Agnihotri, S., Mukherji, S., Mukherji, S., 2014. Size-controlled silver nanoparticles synthesized over the range $5-100 \mathrm{~nm}$ using the same protocol and their antibacterial efficacy. RSC Adv. 4, 3974-3983. https://doi.org/10.1039/C3RA44507K.

Allsopp, D., 2004. Introduction to biodeterioration. Int. Biodeterior. 24, 69-70. https:// doi.org/10.1016/0265-3036(88)90076-0.

Archer, N.K., Mazaitis, M.J., Costerton, J.W., Leid, J.G., Powers, M.E., Shirtliff, M.E., 2011. Properties, Regulation and Roles in Human Disease Staphylococcus aureus Biofilms. pp. 445-459.

Arunachalam, R., Dhanasingh, S., Kalimuthu, B., Uthirappan, M., Rose, C., Mandal, A.B., 2012. Phytosynthesis of silver nanoparticles using Coccinia grandis leaf extract and its application in the photocatalytic degradation. Colloids Surfaces B Biointerfaces 94 , 226-230. https://doi.org/10.1016/j.colsurfb.2012.01.040.

Badawy, a. M.E., Luxton, T.P., Silva, R.G., Scheckel, K.G., Suidan, M.T., Tolaymat, T.M., El Badawy, A.M., Luxton, T.P., Silva, R.G., Scheckel, K.G., Suidan, M.T., Tolaymat, T.M., Badawy, a. M.E., Luxton, T.P., Silva, R.G., Scheckel, K.G., Suidan, M.T. Tolaymat, T.M., 2010. Impact of environmental conditions (pH, ionic strength,and electrolyte type) on the surface charge and aggregation of silver nanoparticle suspensions. Environ. Sci. Technol. 44, 1260-1266. https://doi.org/10.1021/ es902240k.

Baker, S., Rakshith, D., Kavitha, K.S., Santosh, P., Kavitha, H.U., Rao, Y., Satish, S., 2013. Plants: emerging as nanofactories towards facile route in synthesis of nanoparticles. Bioimpacts 3, 111-117. https://doi.org/10.5681/bi.2013.012.

Banasiuk, R., Krychowiak, M., Swigon, D., Tomaszewicz, W., Michalak, A., Chylewska, A., Ziabka, M., Lapinski, M., Koscielska, B., Narajczyk, M., Krolicka, A., 2017. Carnivorous plants used for green synthesis of silver nanoparticles with broad-spectrum antimicrobial activity. Arab. J. Chem 11, 1-14. https://doi.org/10.1016/j. arabjc. 2017.11.013.

Banerjee, I., Pangule, R.C., Kane, R.S., 2011. Antifouling coatings: recent developments in the design of surfaces that prevent fouling by proteins, bacteria, and marine organisms. Adv. Mater. 23, 690-718. https://doi.org/10.1002/adma.201001215.

Bastos, D.H.M., Fornari, A.C., Queiroz, Y.S., Torres, E.A.F.S., 2006. Bioactive compounds content of chimarr??o infusions related to the moisture of yerba mat?? (Ilex paraguariensis) leaves. Braz. Arch. Biol. Technol. 49, 399-404. https://doi.org/10.1590/ S1516-89132006000400007.

Bellotti, N., Salvatore, L., Deyá, C., Del Panno, M.T., del Amo, B., Romagnoli, R., 2013. The application of bioactive compounds from the food industry to control mold growth in indoor waterborne coatings. Colloids Surfaces B Biointerfaces 104, 140-144. https://doi.org/10.1016/j.colsurfb.2012.11.037.

Bellotti, N., Del Amo, B., Romagnoli, R., 2014. Assessment of tannin antifouling coatings by scanning electron microscopy. Prog. Org. Coating 77, 1400-1407. https://doi.org/ 10.1016/j.porgcoat.2014.05.004.

Bellotti, N., Romagnoli, R., Quintero, C., Domínguez-Wong, C., Ruiz, F., Deyá, C., 2015. Nanoparticles as antifungal additives for indoor water borne paints. Prog. Org. Coating 86, 33-40. https://doi.org/10.1016/j.porgcoat.2015.03.006.

Cao, G., 2004. Nanostructures \& Nanomaterials.

Chung, P.Y., Toh, Y.S., 2014. Anti-biofilm agents: recent breakthrough against multi-drug resistant Staphylococcus aureus. Pathog. Dis 70, 231-239. https://doi.org/10.1111/ 2049-632X.12141.

Dominguez-Wong, C., Loredo-Becerra, G.M., Quintero-González, C.C., Noriega-Treviño, M.E., Compeán-Jasso, M.E., Niño-Martínez, N., Dealba-Montero, I., Ruiz, F., 2014. Evaluation of the antibacterial activity of an indoor waterborne architectural coating containing $\mathrm{Ag} / \mathrm{TiO} 2$ under different relative humidity environments. Mater. Lett. 134, 103-106. https://doi.org/10.1016/j.matlet.2014.07.067.

Donlan, R.M., 2002. Biofilms: microbial life on surfaces. Emerg. Infect. Dis. 8, 881-890. https://doi.org/10.3201/eid0809.020063.

Durán, N., Marcato, P.D., De Souza, G.I.H., Alves, O.L., Esposito, E., 2007. Antibacterial effect of silver nanoparticles produced by fungal process on textile fabrics and their effluent treatment. J. Biomed. Nanotechnol. 3, 203-208. https://doi.org/10.1166/ jbn.2007.022.

Durán, N., Durán, M., de Jesus, M.B., Seabra, A.B., Fávaro, W.J., Nakazato, G., 2016. Silver nanoparticles: a new view on mechanistic aspects on antimicrobial activity. Nanomedicine Nanotechnology. Biol. Med. 12, 789-799. https://doi.org/10.1016/j. nano.2015.11.016.

Edison, T.J.I., Sethuraman, M.G., 2012. Instant green synthesis of silver nanoparticles using Terminalia chebula fruit extract and evaluation of their catalytic activity on reduction of methylene blue. Process Biochem. 47, 1351-1357. https://doi.org/10. 1016/j.procbio.2012.04.025.

Elbeshehy, E.K.F., Elazzazy, A.M., Aggelis, G., 2015. Silver nanoparticles synthesis mediated by new isolates of Bacillus spp., nanoparticle characterization and their activity against Bean Yellow Mosaic Virus and human pathogens. Front. Microbiol. 6, 1-13. https://doi.org/10.3389/fmicb.2015.00453.

Falkiewicz-Dulik, M., Janda, K., Wypych, G., Falkiewicz-Dulik, M., Janda, K., Wypych, G., 2015. Industrial biocides. In: Handbook of Material Biodegradation, Biodeterioration, and Biostablization. Elsevier, pp. 33-65. https://doi.org/10.1016/B978-1-89519887-4.50005-0.

Fernández, M.A., Bellotti, N., 2017. Silica-based bioactive solids obtained from modified diatomaceous earth to be used as antimicrobial filler material. Mater. Lett. 194. https://doi.org/10.1016/j.matlet.2017.01.144.

Francescato, L.N., Debenedetti, S.L., Schwanz, T.G., Bassani, V.L., Henriques, A.T., 2013. Identification of phenolic compounds in Equisetum giganteum by LC-ESI-MS/MS and a new approach to total flavonoid quantification. Talanta 105, 192-203. https://doi. org/10.1016/j.talanta.2012.11.072.

Gaylarde, C.C., Morton, L.H.G., Loh, K., Shirakawa, M.A., 2011. Biodeterioration of external architectural paint films - a review. Int. Biodeterior. Biodegrad. 65, 1189-1198. https://doi.org/10.1016/j.ibiod.2011.09.005.

Gerba, C., Bright, K., Silvestry-rodriguez, N., Sicairos-ruelas, E.E., 2007. Reviews of Environmental Contamination and Toxicology, vol. 191. https://doi.org/10.1007/ 978-0-387-69163-3.

Gorchev, H.G., Ozolins, G., 2011. WHO guidelines for drinking-water quality. WHO Chron. 38, 104-108. https://doi.org/10.1016/S1462-0758(00)00006-6.

Gurunathan, S., Han, J.W., Kwon, D.N., Kim, J.H., 2014. Enhanced antibacterial and antibiofilm activities of silver nanoparticles against Gram-negative and Gram-positive bacteria. Nanoscale Res. Lett. 9, 1-17. https://doi.org/10.1186/1556-276X-9-373.

He, H., Veneklaas, E.J., Kuo, J., Lambers, H., 2014. Physiological and ecological significance of biomineralization in plants. Trends Plant Sci. 19, 166-174. https://doi. org/10.1016/j.tplants.2013.11.002.

Hendessi, S., Sevinis, E.B., Unal, S., Cebeci, F.C., Menceloglu, Y.Z., Unal, H., 2016. Antibacterial sustained-release coatings from halloysite nanotubes/waterborne polyurethanes. Prog. Org. Coating 101, 253-261. https://doi.org/10.1016/j. porgcoat.2016.09.005.

Holtz, R.D., Lima, B.A., Souza Filho, A.G., Brocchi, M., Alves, O.L., 2012. Nanostructured silver vanadate as a promising antibacterial additive to water-based paints. Nanomedicine Nanotechnology. Biol. Med. 8, 935-940. https://doi.org/10.1016/j nano.2011.11.012

Huang, J., Li, Q., Sun, D., Lu, Y., Su, Y., Yang, X., Wang, H., Wang, Y., Shao, W., He, N., Hong, J., Chen, C., 2007. Biosynthesis of silver and gold nanoparticles by novel sundried Cinnamomum camphora leaf. Nanotechnology 18. https://doi.org/10 1088/0957-4484/18/10/105104.

Humphreys, H., 2014. Self-disinfecting and microbiocide-impregnated surfaces and fabrics: what potential in interrupting the spread of healthcare-associated infection? Clin. Infect. Dis. 58, 848-853. https://doi.org/10.1093/cid/cit765.

Jaiswal, S., Bhattacharya, K., Sullivan, M., Walsh, M., Creaven, B.S., Laffir, F., Duffy, B., McHale, P., 2013. Non-cytotoxic antibacterial silver-coumarin complex doped sol-gel coatings. Colloids Surfaces B Biointerfaces 102, 412-419. https://doi.org/10.1016/j. colsurfb.2012.07.047.

Kalimuthu, K., Suresh Babu, R., Venkataraman, D., Bilal, M., Gurunathan, S., 2008. Biosynthesis of silver nanocrystals by Bacillus licheniformis. Colloids Surfaces B Biointerfaces 65, 150-153. https://doi.org/10.1016/j.colsurfb.2008.02.018.

Kasprowicz, M.J., Kozioł, M., Gorczyca, A., 2010. The effect of silver nanoparticles on phytopathogenic spores of Fusarium culmorum. Can. J. Microbiol. 56, 247-253. https://doi.org/10.1139/W10-012.

Kim, K.J., Sung, W.S., Suh, B.K., Moon, S.K., Choi, J.S., Kim, J.G., Lee, D.G., 2009. Antifungal activity and mode of action of silver nano-particles on Candida albicans. Biometals 22, 235-242. https://doi.org/10.1007/s10534-008-9159-2.

Krishnaraj, C., Jagan, E.G., Rajasekar, S., Selvakumar, P., Kalaichelvan, P.T., Mohan, N., 2010. Synthesis of silver nanoparticles using Acalypha indica leaf extracts and its antibacterial activity against water borne pathogens. Colloids Surfaces B Biointerfaces 76, 50-56. https://doi.org/10.1016/j.colsurfb.2009.10.008.

Kumar, V., Yadav, S.K., 2009. Plant-mediated synthesis of silver and gold nanoparticles and their applications. J. Chem. Technol. Biotechnol. 84, 151-157. https://doi.org/ 10.1002/jctb.2023.

Kumar, A., Vemula, P.K., Ajayan, P.M., John, G., 2008. Silver-nanoparticle-embedded antimicrobial paints based on vegetable oil. Nat. Mater. 7, 236-241. https://doi.org/ 10.1038/nmat2099.

Kumar, S., Singh, M., Halder, D., Mitra, A., 2014. Mechanistic study of antibacterial activity of biologically synthesized silver nanocolloids. Colloids Surfaces A Physicochem. Eng. Asp 449, 82-86. https://doi.org/10.1016/j.colsurfa.2014.02.027.

Kvítek, L., Panáček, A., Soukupová, J., Kolář, M., Večeřová, R., Prucek, R., Holecová, M., Zbořil, R., 2008. Effect of surfactants and polymers on stability and antibacterial activity of silver nanoparticles (NPs). J. Phys. Chem. C 112, 5825-5834. https://doi. org/10.1021/jp711616v.

Landge, S., Ghosh, D., Aiken, K., 2017. Solvent-free synthesis of nanoparticles, green chemistry: an inclusive approach. https://doi.org/10.1016/B978-0-12-809270-5. 00022-4. 
Le Ouay, B., Stellacci, F., 2015. Antibacterial activity of silver nanoparticles: a surface science insight. Nano Today 10, 339-354. https://doi.org/10.1016/j.nantod.2015. 04.002.

Lok, C., Ho, C., Chen, R., He, Q., 2006. Proteomic analysis of the mode of antibacteria action of silver nanoparticles. Proteome Res 916-924. https://doi.org/10.1021/ pr0504079.

M07-A9, 2012. Methods for dilution antimicrobial susceptibility tests for bacteria that grow Aerobically ; approved standard - ninth edition, methods for dilution antimicrobial susceptibility tests for bacteria that grow aerobically; approved standarninth edition. https://doi.org/10.4103/0976-237X.91790.

M38-P, 2008. Reference Method for Broth Dilution Antifungal Susceptibility Testing of Filamentous Fungi; Approved Standard, second ed. CLSI Document M38-A2.

Machado, D.G., Kaster, M.P., Binfaré, R.W., Dias, M., Santos, A.R.S., Pizzolatti, M.G. Brighente, I.M.C., Rodrigues, A.L.S., 2007. Antidepressant-like effect of the extract from leaves of Schinus molle L. in mice: evidence for the involvement of the monoaminergic system. Prog. Neuro Psychopharmacol. Biol. Psychiatr. 31, 421-428. https://doi.org/10.1016/j.pnpbp.2006.11.004.

Matan, N., Matan, N., Ketsa, S., 2012. Effect of heat curing on antifungal activities of anise oil and garlic oil against Aspergillus Niger on rubberwood. Int. Biodeterior. Biodegrad. 75, 150-157. https://doi.org/10.1016/j.ibiod.2012.03.012.

Mitra, C., Gummadidala, P.M., Afshinnia, K., Merrifield, R.C., Baalousha, M., Lead, J.R., Chanda, A., 2017. Citrate-coated silver nanoparticles growth-independently inhibit aflatoxin synthesis in Aspergillus parasiticus. Environ. Sci. Technol. 51, 8085-8093. https://doi.org/10.1021/acs.est.7b01230.

Mittal, A.K., Chisti, Y., Banerjee, U.C., 2013. Synthesis of metallic nanoparticles using plant extracts. Biotechnol. Adv. 31, 346-356. https://doi.org/10.1016/j.biotechadv. 2013.01.003.

Morones, J.R., Elechiguerra, J.L., Camacho, A., Holt, K., Kouri, J.B., Ramírez, J.T., Yacaman, M.J., 2005. The bactericidal effect of silver nanoparticles. Nanotechnology 16, 2346-2353. https://doi.org/10.1088/0957-4484/16/10/059.

Morton, L.H.G., Surman, S.B., 1994. Biofilms in biodeterioration - a review. Int. Biodeterior. Biodegrad. 34, 203-221. https://doi.org/10.1016/0964-8305(94) 90083-3.

Mulvaney, P., 1996. Surface plasmon spectroscopy of nanosized metal particles. Langmuir 12, 788-800. https://doi.org/10.1021/la9502711.

Nielsen, K.F., 2003. Mycotoxin Production by Indoor Molds, vol. 39. pp. 103-117. https://doi.org/10.1016/S1087-1845(03)00026-4.

Olaf, C.G., Samson, R.A., 2011. Fundamentals of Mold Growth in Indoor Environments and Strategies for Healthy Living. Wageningen Academic Publishers. https://doi. org/10.3920/978-90-8686-722-6.

Pal, S., Tak, Y.K., Song, J.M., 2007. Does the antibacterial activity of silver nanoparticles depend on the shape of the nanoparticle? A study of the gram-negative bacterium Escherichia coli. Appl. Environ. Microbiol. 73, 1712-1720. https://doi.org/10.1128/ AEM.02218-06.

Panáček, A., Kvítek, L., Prucek, R., Kolář, M., Večeřová, R., Pizúrová, N., Sharma, V.K., Nevěčná, T., Zbořil, R., 2006. Silver colloid nanoparticles: synthesis, characterization, and their antibacterial activity. J. Phys. Chem. B 110, 16248-16253. https://doi.org/ 10.1021/jp063826h.

Panáček, A., Kolář, M., Večeřová, R., Prucek, R., Soukupová, J., Kryštof, V., Hamal, P., Zbořil, R., Kvítek, L., 2009. Antifungal activity of silver nanoparticles against Candida spp. Biomaterials 30, 6333-6340. https://doi.org/10.1016/j.biomaterials.2009.07. 065.

Park, K., Park, E.J., Chun, I.K., Choi, K., Lee, S.H., Yoon, J., Lee, B.C., 2011. Bioavailability and Toxicokinetics of citrate-coated silver nanoparticles in rats. Arch Pharm. Res. (Seoul) 34, 153-158. https://doi.org/10.1007/s12272-011-0118-z.

Pasupuleti, V.R., Prasad, Shiekh, R.A., Balam, S.K., Narasimhulu, G., Reddy, C.S., Al, E., 2013. Biogenic silver nanoparticles using Rhinacanthus nasutus leaf extract: synthesis, spectral analysis, and antimicrobial studies. Int. J. Nanomed. 8, 3355-3364.
https://doi.org/10.2147/IJN.S49000.

Pereyra, A.M., Gonzalez, M.R., Rosato, V.G., Basaldella, E.I., 2014. A-type zeolite containing $\mathrm{Ag}+/ \mathrm{Zn} 2+$ as inorganic antifungal for waterborne coating formulations. Prog. Org. Coating 77, 213-218. https://doi.org/10.1016/j.porgcoat.2013.09.008.

Rai, M., Yadav, A., Gade, A., 2009. Silver nanoparticles as a new generation of antimicrobials. Biotechnol. Adv. 27, 76-83. https://doi.org/10.1016/j.biotechadv.2008. 09.002 .

Raza, M., Kanwal, Z., Rauf, A., Sabri, A., Riaz, S., Naseem, S., 2016. Size- and shapedependent antibacterial studies of silver nanoparticles synthesized by wet chemical routes. Nanomaterials 6 (74). https://doi.org/10.3390/nano6040074.

Salem, M.Z.M., Zayed, M.Z., Ali, H.M., Abd El-Kareem, M.S.M., 2016. Chemical composition, antioxidant and antibacterial activities of extracts from Schinus molle wood branch growing in Egypt. J. Wood Sci. 62, 548-561. https://doi.org/10.1007/ s10086-016-1583-2.

Shankar, S.S., Ahmad, A., Sastry, M., 2003. Geranium leaf assisted biosynthesis of silver nanoparticles. Biotechnol. Prog. 19, 1627-1631. https://doi.org/10.1021/ bp034070w.

Sharma, V.K., Yngard, R.A., Lin, Y., 2009. Silver nanoparticles: green synthesis and their antimicrobial activities. Adv. Colloid Interface Sci. 145, 83-96. https://doi.org/10. 1016/j.cis.2008.09.002

Sharmin, E., Zafar, F., Akram, D., Ahmad, S., 2013. Plant oil polyol nanocomposite for antibacterial polyurethane coating. Prog. Org. Coating 76, 541-547. https://doi.org/ 10.1016/j.porgcoat.2012.10.027.

Singh, A.K., 2016. Structure, synthesis, and application of nanoparticles, engineered nanoparticles. https://doi.org/10.1016/B978-0-12-801406-6.00002-9.

Singh, P., Kim, Y.J., Singh, H., Mathiyalagan, R., Wang, C., Yang, D.C., 2015. Biosynthesis of anisotropic silver nanoparticles by bhargavaea indica and their synergistic effect with antibiotics against pathogenic microorganisms. J. Nanomater. https://doi.org/ $10.1155 / 2015 / 234741$.

Singh, P., Kim, Y.J., Wang, C., Mathiyalagan, R., Yang, D.C., 2016a. The development of a green approach for the biosynthesis of silver and gold nanoparticles by using Panax ginseng root extract, and their biological applications. Artif. Cells. Nanomed. Biotechnol 44, 1150-1157. https://doi.org/10.3109/21691401.2015.1011809.

Singh, P., Kim, Y.J., Zhang, D., Yang, D.C., 2016b. Biological synthesis of nanoparticles from plants and microorganisms. Trends Biotechnol. 34, 588-599. https://doi.org/ 10.1016/j.tibtech.2016.02.006.

Stobie, N., Duffy, B., Colreavy, J., McHale, P., Hinder, S.J., McCormack, D.E., 2010. Dualaction hygienic coatings: benefits of hydrophobicity and silver ion release for protection of environmental and clinical surfaces. J. Colloid Interface Sci. 345, 286-292. https://doi.org/10.1016/j.jcis.2010.02.009.

Terenteva, E.A., Apyari, V.V., Dmitrienko, S.G., Zolotov, Y.A., 2015. Formation of plasmonic silver nanoparticles by flavonoid reduction: a comparative study and application for determination of these substances. Spectrochim. Acta Part A Mol. Biomol. Spectrosc 151, 89-95. https://doi.org/10.1016/j.saa.2015.06.049.

Thakkar, K.N., Mhatre, S.S., Parikh, R.Y., 2010. Biological synthesis of metallic nanoparticles. Nanomedicine Nanotechnology. Biol. Med. 6, 257-262. https://doi.org/10. 1016/j.nano.2009.07.002.

Makarov, V.V., et al., 2014. "Green" nanotechnologies: synthesis of metal nanoparticles using plants. Acta Naturae 6, 35-44. https://doi.org/10.1039/c1gc15386b.

Weber, D.J., Rutala, W.A., 2013. Self-disinfecting surfaces: review of current methodologies and future prospects. Am. J. Infect. Contr. 41, S31-S35. https://doi.org/10. 1016/j.ajic.2012.12.005

WHO, 1996. second ed. Guidelines for Drinking-water Quality, vol. 2. pp. 15 Health Criteria and Other Supporting Information. Who 19962.

Zielecka, M., Bujnowska, E., Kępska, B., Wenda, M., Piotrowska, M., 2011. Antimicrobial additives for architectural paints and impregnates. Prog. Org. Coating 72, 193-201. https://doi.org/10.1016/j.porgcoat.2011.01.012. 